\title{
汎用マイコンモジュールによるスマート 構造のセルフセンシング振動制御*1
}

\section{Self-Sensing Piezoelectric Actuation for Smart Structure using Affordable Micro-controller}

\author{
南部 陽 介 $^{* 2} \cdot$ 山 元 翔 $太^{* 3} \cdot$ 千 葉 正 克*2 \\ Yohsuke Nambu, Shota Yamamoto and Masakatsu ChibA
}

Key Words : Smart Structure, Self-sensing Vibration Control, Micro-controller

\begin{abstract}
The purpose of this paper is to verify the effectiveness of self-sensing piezoelectric actuation using an affordable micro-controller. In recent years, space structural systems have been required high precision and high functionality for advanced space missions. Vibration control is one of important issues to realize high mirror accuracy of antennas for a high-resolution observation and a high-capacity communication. Generally, active vibration control needs not only actuators and sensors, but also AD/DA converters and highly advanced arithmetic processing. However, it is difficult to mount complex and heavy devices on satellites. A compact and modulized unit for vibration control is necessary. Then, this study focused on an affordable micro-controller that is small, low power consumption and easily-available. And self-sensing actuation was chosen as the vibration control technique to reduce in size and weight of the control system. Numerical simulations and experiments to damp free decay vibration and harmonic vibration of a smart cantilever were demonstrated, and show that the presented approach is very useful for realizing the active vibration control unit.
\end{abstract}

1. 緒

言

本研究の目的は, マイコンを用いたセルフセンシング振 動制御の有効性を示し, 宇宙空間における超高精度スマー 卜構造システムの実現に向けた基本技術を習得することで ある. 近年の宇宙ミッションの高度化に伴い, 構造システ ムにおいても, より高精度・高機能なものか求められてい る.特に, 大容量通信を行うための宇宙用アンテナのよう な大型宇宙構造物においては, 構造の柔軟性に起因する変 形や振動が無視できない問題となるため, 宇宙構造物の振 動制御・形状制御は極めて重要な課題である.宇宙構造物の 振動制御において，圧電素子を用いた制振手法が注目され ている ${ }^{1,2)}$. 圧電素子は, 力を加えると電圧を発生する圧電 効果と, 逆に電圧を印加すると力を生じる逆圧電効果を併 せ持つ.これらの効果を利用して，センサとアクチュエー タ両方の機能を果たすことができる．

振動制御は, 大別して, 能動的, 受動的, 準能動的手法の 3 種類に分けることができる. 能動的振動制御では，外部か ら適切なタイミングでエネルギーを供給することによって， 高い制振効果を得ることができる。しかし，設計された制 御系が適切でない場合には，系が不安定になってしまう恐 れがある.さらに, 外部電力, センサ, アクチュエータ,コ ントローラからなる複雑な制御装置が必要となる.圧電素

\footnotetext{
*1 C) 2013 日本航空宇宙学会

平成 25 年 1 月 30 日原稿受付

*2 大阪府立大学大学院工学研究科航空宇宙工学分野

*3 大阪府立大学大学院工学研究科航空宇宙海洋系専攻
}

子を用いた能動的振動制御の中で特筆すべきは,一片の圧 電素子にセンサとアクチュエータ両方の機能を持たせるセ ルフセンシング・アクチュエーションである. Dosch ら ${ }^{3)}$ や Anderson ら ${ }^{4)}$ は, ブリッジ回路により圧電素子の観測 出力信号に混在する制御入力信号とセンサ出力信号を分離 できることを示した .ブリッジ回路を用いたセルフセンシ ングの実装上の最も大きな問題は, ブリッジ回路のバラン スを正確に保つことが困難であるという点である .これは， ブリッジ回路を構成する圧電素子のキャパシタンスの值の 正確な推定が困難であることに起因する .この問題に対処 するために, Takigami ら ${ }^{5)}$ はブリッジ回路の参照キャパシ 夕側をソフトウェア上で構成する仮想ブリッジ回路を用い る手法を提案した . セルフセンシング振動制御では外部セ ンサが不要なため, 制振システムの小型・軽量化が実現で きる．また，センサとアクチュエータの完全な共配置が可 能であるため, 閉ループ系の安定性に対して優れている .

受動的振動制御では，外部から系へエネルギーを注入し ないため，系は常に安定である.しかし, 能動的振動制御 に比へ制振効果が小さく，外部環境の变化にも弱くなると いう欠点がある。圧電素子を利用した受動的制振手法には， 圧電素子が電圧発生器とキャパシタの特性を持つという性 質を活かした特筆すべきものがある． Forward ${ }^{6)}$ は，圧電 素子をインダクタとレジスタから構成されるシャント回路 に接続し，構造物の機械的エネルギーを電気回路に移動・ 消散させることで振動を減衰させる手法を提案した .さら に, Hagood ら ${ }^{7)}$ は共振シャン卜回路を動吸振器として扱 えることを示した . 兴の後, 樣々なシャント回路を用いて 
振動減衰が試みられた8,9)。

準能動的制振手法は, 能動的制振手法と受動的制振手法 の中間である . Richard ら ${ }^{10)}$ や Clark $^{11)}$ は, 圧電素子と受 動回路の間にスイッチを付け , スイッチを適切なタイミング で開閉することで能動的に系のパラメータをコントロール し, 受動的振動制御に比べて優れた制振効果を得ることが できるスイッチング回路を提案した . Richard ら ${ }^{12)}$, Corr $ら^{13)}$, Onoda ら ${ }^{14)}$ は, 共振シャント回路とスイッチ制御 を用いたエネルギー回生型準能動的振動制御手法を提案し た . また , Makihara ら ${ }^{15)}$ は拡張システム方程式とカルマ ンフィルタ及びスイッチング回路を用いたセルフセンシン グの手法を提案した．準能動的制御では系に対する直接的 なエネルギーの注入はないため, 能動的制御に比べ安定性 に優れ，かつ受動的制御に比べ制振効果が高い.しかし， 能動的に系のパラメータをコントロールするために, 能動 的制御と同樣に, 複雑な制御装置が必要である.受動的振 動制御のように，外部からの電力供給を必要としない準能

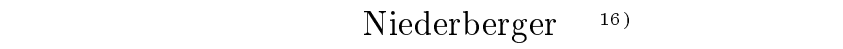
れた自動スイッチング回路がある.さらに , Takeuchi ら ${ }^{17)}$ や Makihara ら ${ }^{18)}$ は圧電素子が発生する電力でスイッチン グ回路を制御するためのマイコンを駆動させる，セルフパ ワードデジタル振動制御の手法を提案した . マイコンを利 用しているため，高度な制御則を実装することもできる．

以上で述べたように，圧電素子を用いた振動制御につい ては多くの研究がなされてきた.しかし，宇宙構造物の振 動制御への応用例は未だなく，実用化されていない．超高 精度構造物を実現する方法として, スマート構造に対する 需要があるにもかかわらず, 光の利用が実現していない理 由のひとつに, 宇宙実証されていない技術であることが挙 げられる . 従来の研究は, スマート構造の一部機能を抽出 して, 最も重要と考えられる機能のみを実証することに重 点を置いたものであった . 一方, 宇宙構造物への応用を視 野に入れた場合, スマート構造をシステムとして捉え, シ ステムとしての制振性能を実証することが重要となる．つ まり, ハイスペックなパソコンや $\mathrm{AD} / \mathrm{DA}$ 変換器をはじめ とする多くの支援装置に補助されているスマート構造では なく，自己完結したスマート構造の実証実験が必要である．

以上を鑑み, 本研究では, スマート構造の宇宙実証を目 指し，マイコンモジュールを用いたセルフセンシング振動 制御の有効性を示すことを目的とする．本稿では，片持ち 梁を対象に, シミュレーションと実験により本手法の有効 性を検証する .

\section{2. 振 動 制 御 則}

2.1 セルフセンシング用ブリッジ回路 第 1 図は，ひ ずみ測定のための RC ブリッジ回路3)である . ブリッジ回 路内の電圧 $v_{1}, v_{2}$ は，光れ光れ，

$$
\begin{aligned}
& v_{1}=\frac{C_{p}}{C_{p}+C_{1}}\left(v_{p}+v_{c}\right) \\
& v_{2}=\frac{R_{1}}{R_{1}+R_{2}} v_{c}
\end{aligned}
$$

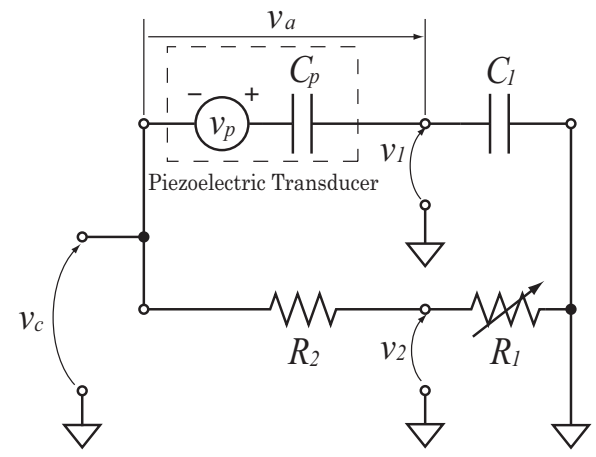

第 1 图 ひずみ検出用 RC ブリッジ回路

と表せる.ここで, $R_{1}$ はブリッジ回路調整のための可変抵 抗值， $R_{2}$ は固定抵抗值， $C_{1}$ は固定コンデンサの静電容量， $C_{p}$ は圧電素子の静電容量である. $v_{c}$ は制御電圧,$v_{p}$ は機 械的ひずみに比例する圧電素子の発生電圧である . センサ 電圧 $v_{s}$ を $v_{s} \equiv v_{1}-v_{2}$ と定義すると，

$$
v_{s}=\frac{C_{p}}{C_{p}+C_{1}} v_{p}+\left\{\frac{C_{p}}{C_{p}+C_{1}}-\frac{R_{1}}{R_{1}+R_{2}}\right\} v_{c}
$$

と表せる．ここで, ブリッジ回路の平衡条件

$$
\frac{C_{p}}{C_{p}+C_{1}}=\frac{R_{1}}{R_{1}+R_{2}}
$$

を満たすように回路のバランスをとると，

$$
v_{s}=\frac{C_{p}}{C_{p}+C_{1}} v_{p}
$$

のように $v_{c}$ の影響を取り除き，圧電素子のひずみに比例す る信号 $v_{p}$ のみを抽出することができる．

2.2 運動方程式 第 2 図のような圧電素子が貼付され た片持ち梁を考える. 圧電素子か貼付された片持ち梁の運 動方程式は, 以下のように表される .

$$
\begin{aligned}
\left\{\rho_{b} A_{b}\right. & \left.+\rho_{p} A_{p} g(x)\right\} \frac{\partial^{2} w}{\partial t^{2}}+\left\{E_{b} I_{b}+E_{p} I_{p} g(x)\right\} \frac{\partial^{4} w}{\partial x^{4}} \\
& +b_{p} J_{p} \frac{\partial^{2}\left(D_{z} g(x)\right)}{\partial x^{2}}=0
\end{aligned}
$$

ここで, $g(x)$ は 2 つのヴィサイドの階段関数 $H(x)$ を用 いて，以下のように定義される．

$$
g(x) \equiv H\left(x-x_{2}\right)-H\left(x-x_{1}\right)
$$

また, $D_{z}$ は, ガウスの定理より, 圧電素子の電荷 $q(t)$ を 用いて，

$$
D_{z}=\frac{q(t)}{d_{p}\left(x_{2}-x_{1}\right)}
$$

と表される .

梁の $n$ 次モードまでを考慮した場合，梁の変位 $w(x, t)$ は, モード関数 $\Phi_{k}(x)$, モード変位 $\xi_{k}(t)$ を用いて以下の ように表される .

$$
w(x, t)=\sum_{k=1}^{n} \xi_{k}(t) \Phi_{k}(x)
$$


汎用マイコンモジュールによるスマート構造のセルフセンシング振動制御（南部陽介・山元翔太・千葉正克）

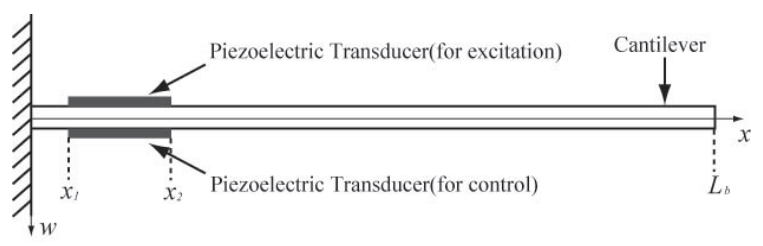

第 2 図 圧電素子が貼付された片持ち梁

なお，モード関数 $\Phi_{k}(x)$ は, 圧電素子を貼付した片持ち梁 のモード関数とする .このとき, 梁の運動方程式は ,

$$
\boldsymbol{M}_{a} \ddot{\boldsymbol{\xi}}(t)+\boldsymbol{K}_{a} \boldsymbol{\xi}(t)=\boldsymbol{B}_{a}^{t} q(t)+\boldsymbol{f}(t)
$$

となる．なお，式 (9) のマトリクスの定義は , 付録 A.1 に 載せている。

第 1 図に示すブリッジ回路を用いる場合, 以下の式が成 り立つ.

$$
v_{c}(t)=v_{p}(t)+\frac{q(t)}{C_{p}}+\frac{q(t)}{C_{1}}
$$

ここで, 圧電素子の発生電圧は，

$$
v_{p}(t)=-\boldsymbol{B}_{a}^{t} \boldsymbol{\xi}(t)
$$

と表されるので , これを式 (10)に代入すると ,

$$
v_{c}(t)=-\boldsymbol{B}_{a}^{t} \boldsymbol{\xi}(t)+\frac{q(t)}{C_{a}}
$$

となる．ただし，

$$
C_{a} \equiv \frac{C_{p} C_{1}}{C_{p}+C_{1}}
$$

である . 式 $(12)$ を $q(t)$ について書き換えると , 以下のよ うになる

$$
q(t)=\left(v_{c}(t)+\boldsymbol{B}_{a}^{t} \boldsymbol{\xi}(t)\right) C_{a}
$$

これを式 (9) に代入すると，

$$
\boldsymbol{M}_{a} \ddot{\boldsymbol{\xi}}(t)+\left(\boldsymbol{K}_{a}-C_{a} \boldsymbol{B}_{a}^{2}\right) \boldsymbol{\xi}(t)=\boldsymbol{B}_{a} C_{a} v_{c}(t)+\boldsymbol{f}(t)(15)
$$

と表される.両辺に左から $M_{a}^{-1}$ を掛け, さらにモード減 衰比行列 $\Xi$ を導入すると，

$$
\ddot{\boldsymbol{\xi}}(t)+\boldsymbol{\Xi} \dot{\boldsymbol{\xi}}(t)+\boldsymbol{\Omega} \boldsymbol{\xi}(t)=\boldsymbol{B}_{1} v_{c}(t)+\boldsymbol{B}_{2} \boldsymbol{f}(t)
$$

となる .

2.3 制御則 線形システムの状態方程式は

$$
\dot{\boldsymbol{z}}(t)=\boldsymbol{A} \boldsymbol{z}(t)+\boldsymbol{B} \boldsymbol{u}(t)+\boldsymbol{v}(t)
$$

と表される.ここに, $\boldsymbol{z}(t)$ は状態変数, $\boldsymbol{v}(t)$ はシステム外 乱行列, $\boldsymbol{u}(t)$ は制御入力である.式 $(16)$ より，

$$
\begin{aligned}
\boldsymbol{A} & \equiv\left[\begin{array}{cc}
0 & \boldsymbol{I} \\
-\boldsymbol{\Omega} & -\boldsymbol{\Xi}
\end{array}\right] \\
\boldsymbol{B} & \equiv\left[\begin{array}{ll}
0 & \boldsymbol{B}_{1}
\end{array}\right]^{t}
\end{aligned}
$$

$$
\boldsymbol{z} \equiv\left[\begin{array}{ll}
\boldsymbol{\xi} & \dot{\boldsymbol{\xi}}
\end{array}\right]^{t}
$$

であり, $\boldsymbol{u}(t)=\left[v_{c}(t)\right]$ である.

また，出力方程式は次式で表される．

$$
\boldsymbol{y}(t)=\boldsymbol{C} \boldsymbol{z}(t)+\boldsymbol{w}(t)
$$

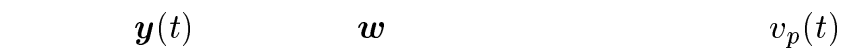
のみが観測できるとき， $\boldsymbol{y}(t)=\left[v_{p}(t)\right]$ であり，

$$
\boldsymbol{C} \equiv\left[\begin{array}{ll}
-\boldsymbol{B}_{a}^{t} & 0
\end{array}\right]
$$

となる．

本研究では, カルマンフィルタをオブザーバーとして用 いるとすると , システムの状態空間モデルは次のように表 される

$$
\begin{aligned}
\dot{\hat{\boldsymbol{z}}}(t) & =\boldsymbol{A} \hat{\boldsymbol{z}}(t)+\boldsymbol{B} \boldsymbol{u}(t)+\boldsymbol{L}[\boldsymbol{y}(t)-\hat{\boldsymbol{y}}(t)] \\
& =[\boldsymbol{A}-\boldsymbol{L} \boldsymbol{C}] \hat{\boldsymbol{z}}(t)+\boldsymbol{B} \boldsymbol{u}(t)+\boldsymbol{L} \boldsymbol{y}(t)
\end{aligned}
$$

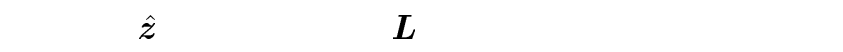
常な確率過程において, $\boldsymbol{v}$ と $\boldsymbol{w}$ の期待值が 0 , すなわち，

$$
E\{\boldsymbol{v}(t)\}=\mathbf{0}, \quad E\{\boldsymbol{w}(t)\}=\mathbf{0}
$$

であるとし , 共分散行列は

$$
\begin{aligned}
E\left\{\boldsymbol{v}(t) \boldsymbol{v}^{t}(\tau)\right\} & =\boldsymbol{V} \delta(t-\tau) \\
E\left\{\boldsymbol{w}(t) \boldsymbol{w}^{t}(\tau)\right\} & =\boldsymbol{W} \delta(t-\tau)
\end{aligned}
$$

と表されるとする .このとき, 式 (19) 中のカルマンゲイ ン $\boldsymbol{L}$

$$
\boldsymbol{L}=\boldsymbol{S} \boldsymbol{C}^{t} \boldsymbol{W}^{-1}
$$

と表される. $\boldsymbol{S}$ はリッカチ方程式 (23) の解である.

$$
\boldsymbol{A} \boldsymbol{S}+\boldsymbol{S} \boldsymbol{A}^{t}-\boldsymbol{S} \boldsymbol{C}^{t} \boldsymbol{W}^{-1} \boldsymbol{C S}+\boldsymbol{V}=\mathbf{0}
$$

入力 $\boldsymbol{u}(t)$ は, 推定状態量 $\hat{\boldsymbol{z}}$ を用いたフィードバック制 御入力とする.すなわち ,

$$
\boldsymbol{u}(t)=-\boldsymbol{K} \hat{\boldsymbol{z}}(t)
$$

とする . $\boldsymbol{K}$ は状態フィードバックゲインである . LQR 理 論19) では, 次のような評価関数 $J$ を最小にする状態フィー ドバックゲインベクトル $K$ を用いる .

$$
J=\int_{0}^{\infty}\left(\hat{z}^{t} \boldsymbol{Q} \hat{z}+\boldsymbol{u}^{t} \boldsymbol{r u}\right) d t
$$

ここで， $Q$ は状態量ベクトルに関する重み行列， $\boldsymbol{r}$ は制御 量ベクトルに関する重み行列である．このとき， $J$ を最小 にする最適ゲインは式 (26) で与えられる .

$$
\boldsymbol{K}=-\boldsymbol{r}^{-1} \boldsymbol{B}^{t} \boldsymbol{P}
$$

ただし，P はリッカチ方程式 (27) の解である .

$$
\boldsymbol{A}^{t} \boldsymbol{P}+\boldsymbol{P} \boldsymbol{A}-\boldsymbol{P} B \boldsymbol{r}^{-1} \boldsymbol{B}^{t} \boldsymbol{P}+\boldsymbol{Q}=\mathbf{0}
$$




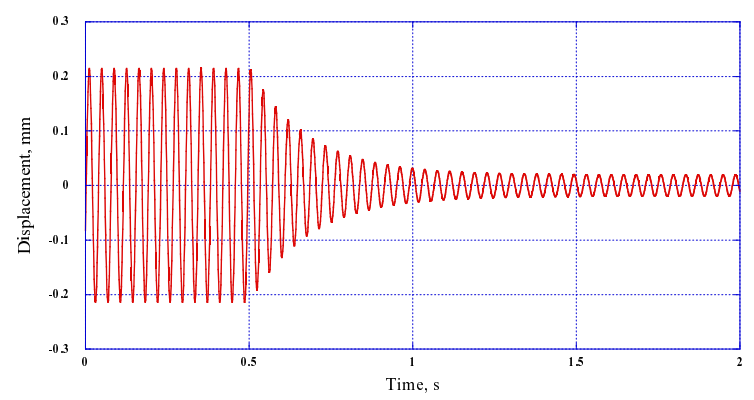

第 3 図強制振動の制振シミュレーション結果 : 変位

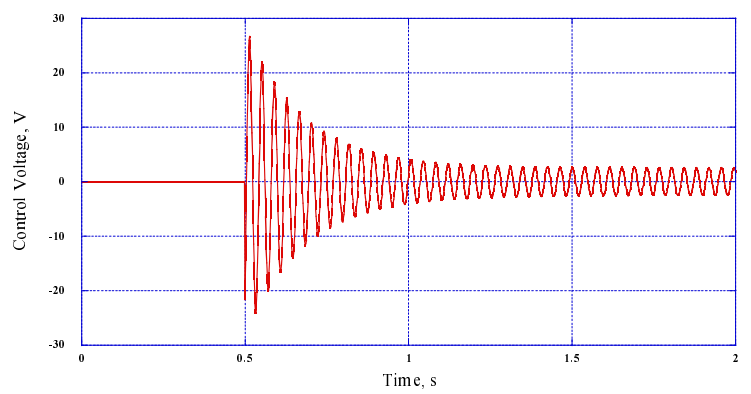

第 4 図強制振動の制振シミュレーション結果 : 制御電圧

3. 片持ち梁の制振シミュレーション

前節で述べた理論を用いて, 梁の強制振動の制振シミュ レーション及び, 自由減衰振動の制振シミュレーションを 行った . 簡単のため, 梁の 1 次モードのみを考慮した . シ ミュレーションに用いた数值パラメータを第 1 表に示す.な お，これらの数值パラメータは，5節で述べる実験条件と 同樣のものである .減衰比 $\zeta$ の值は 0.003 とし, 重み行列 は， $\boldsymbol{Q}=\operatorname{diag}[1,0], \boldsymbol{r}=\operatorname{diag}\left[10^{-11}\right]$ とした . システム外 乱共分散行列 $\boldsymbol{V}$ 及び観測外乱共分散行列 $\boldsymbol{W}$ は, 弚れ光れ $\operatorname{diag}\left[0,10^{-11}\right]$ と $\operatorname{diag}\left[10^{-4}\right]$ とした. ただし，ブリッジ回 路の平衡条件は厳密に満たされているものと仮定した .

\begin{tabular}{clll}
\multicolumn{3}{c}{ 第 1 表 } & シミュレーションに用いた数値パラメータ \\
\hline$L_{b}$ & $320 \mathrm{~mm}$ & $\rho_{b}$ & $2.7 \times 10^{-6} \mathrm{~kg} / \mathrm{mm}^{3}$ \\
$d_{b}$ & $19.5 \mathrm{~mm}$ & $E_{b}$ & $6.9 \mathrm{GPa}$ \\
$h_{b}$ & $3 \mathrm{~mm}$ & $\rho_{p}$ & $8.1 \times 10^{-6} \mathrm{~kg} / \mathrm{mm}^{3}$ \\
$L_{p}$ & $30 \mathrm{~mm}$ & $E_{p}$ & $66 \mathrm{GPa}$ \\
$d_{p}$ & $20 \mathrm{~mm}$ & $b_{p}$ & $-2.87 \times 10^{8} \mathrm{~N} / \mathrm{C}$ \\
$h_{p}$ & $0.5 \mathrm{~mm}$ & $x_{1}$ & $5 \mathrm{~mm}$ \\
& & $x_{2}$ & $35 \mathrm{~mm}$ \\
\hline
\end{tabular}

3.1 強制振動の制振シミュレーション 梁の固有振動数 $(26.33 \mathrm{~Hz})$ の加振力を加え，振幅が定常状態に達した後に， 振動制御を開始した .このとき, 梁の変位と制御電圧のシ ミュレーション結果を第 3 図，第 4 図に示す.第 3 図から， 制振後は定常振幅を約 $90 \%$ 抑制できていることがわかる. また，第 4 図から，制御電圧の最大值は制御開始直後の約 $28 \mathrm{~V}$ であり, 弚の後, 定常状態に遷移するとともに減少し， 約 $3 \mathrm{~V}$ に落ち着くことがわかる.

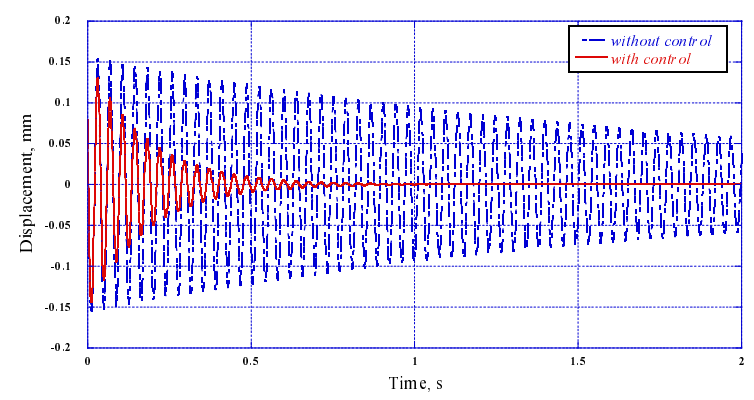

第 5 図 自由減衰振動の制振シミュレーション結果 : 变位

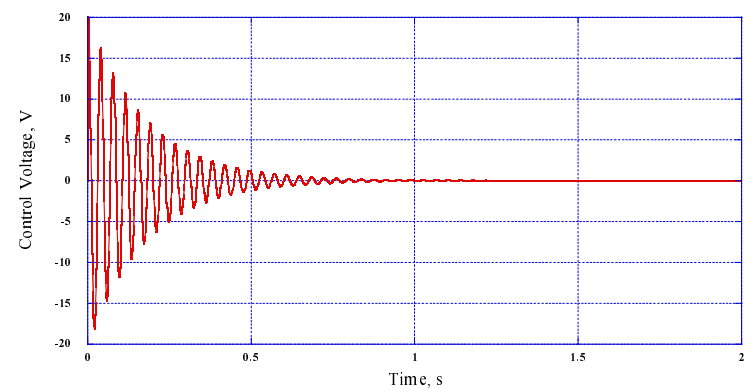

第 6 図 自由減衰振動の制振シミュレーション結果 : 制御電圧

3.2 自由減衰振動の制振シミュレーション 梁の自由 減衰振動に対して, 制振シミュレーションを行った。制御 の有無による梁の自由減衰振動の変位を比較したグラフを 第 5 図に示す．また，制御電圧を第 6 図に示す. 第 5 図か ら，制御ありの場合には，制御なしの場合に比べ，振動が 明らかに早く減衰していることがわかる . また , 第 6 図か ら，制御電圧の最大值は約 $20 \mathrm{~V}$ であることがわかる .

\section{4. mbed}

本研究では,アクティブ制御のプロセッサとして , “mbed” を用いる。“mbed” は第 7 図に示すような，DIP40 pin の ARM 社製マイコンモジュールである ${ }^{20)}$. 動作周波数は 96 $\mathrm{MHz}$ で, $512 \mathrm{~KB}$ のFlash メモリ ,64 KBのSRAM ,USB , Ethernet などの接続機能も備えている .

“mbed” の大きな特徵は, プロクラム組込開発環境の構 築が非常に容易であるという点である.コンパイラなどの 開発ツールは,インターネット上のサーバに揃っており，プ ログラムは C 言語によって組み込むことができる . Web 上 には豊富なライブラリ群が揃っており，例えば SD カードと の通信機能もライブラリを利用することで容易に実装でき る。なお，“mbed”にはまだ宇宙環境下における利用実績 はないが, 現在大阪府立大学が開発を進めている $10 \mathrm{~cm}$ 級 超小型衛星 OPUSAT(2014 年打ち上げ予定) に搭載され， 宇宙実証される予定である .

“mbed" は $\mathrm{AD} / \mathrm{DA}$ 変換が可能であるが, 入出力電圧範 囲が $0 \sim 3.3 \mathrm{~V}$ であるので, 正負の制御電圧が必要となる振 動制御に用いるために, 本研究では第 8 図に示す電圧变換 回路などから構成されるインターフェース回路を実装した . 第 1 図のブリッジ回路もこの中に含まれている . “mbed” 

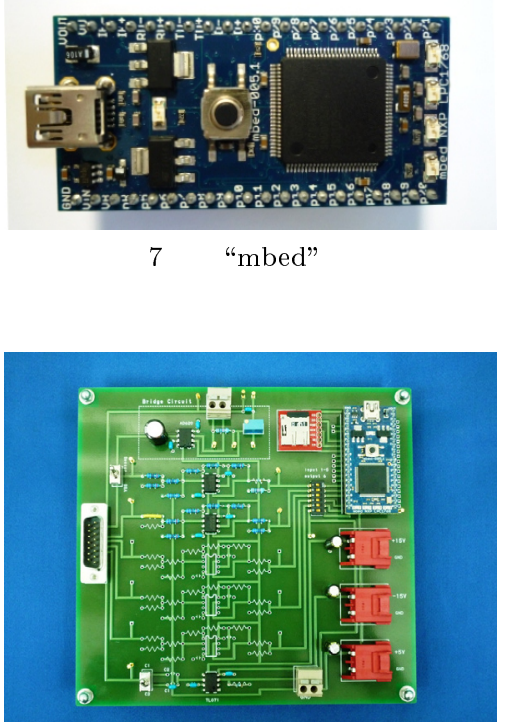

第8図 プリント基板

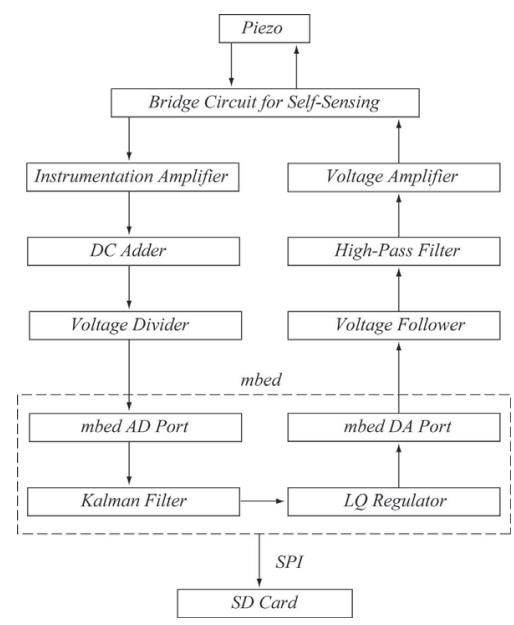

第9図＼cjkstart制御信号のブロック線図

を用いた振動制御における制御信号のブロック線図を第 9 図に示す。

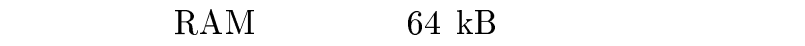
データはSPI通信によりSD カードに保存するようにした . 谷の際, データ書き込みによるタイムロスが振動制御に悪 影響を及ぼすことがないよう注意が必要である。一般に， SD カードにデータを書き込む場合，256 B 単位で書きこ むこととなる．256 B に満たない分は，無意味なデータが 挿入される . また，書き込みの際には，ネゴシエーション が必要となるため, 書き込む回数が多いほどタイムロスが 大きくなる．したがって，256 B のデータが集まってから 書き込みを実行することが, 最も効率的な書き込み方法で ある . 振動制御では高度な演算とデジタル・アナロク変換 が必要となるため, 上記のようなプログラムへの配慮も重 要となる.

\section{5. 片持ち梁のセルフセンシング制振実験}

第 10 図に示す片持ち梁に対して, 強制振動及び自由減衰 振動の制振実験を行った、実験系のブロック線図を第 11 図 に示す. 実験に用いた梁と圧電素子の諸元は，第 1 表と同 樣である . 片持ち梁の固定端付近の両面にはエポキシ系接 着剂により圧電素子 (富士セラミックス製 $\mathrm{C}-90 \mathrm{H}$ ) か貼付 されている . 表側の圧電素子は加振用アクチュエータであ り，アンプを介して電圧発生器と接続されている．裏側の 圧電素子は制振用のセルフセンシングアクチュエータであ り，プリント基板 (第 8 図) 上に実装したブリッジ回路 (第 1 図)に接続されている

また , レーザー変位計 (オムロン社製，ZX2-LD100)を 用いて, 梁の先端付近 $(x=278 \mathrm{~mm})$ の変位を計測した . こ の変位計は計測用であり，振動制御には用いない，変位計 の信号は, データロガーにより記録される .

5.1 強制振動の制振実験 加振用の圧電素子に梁の固 有振動数 $(26.33 \mathrm{~Hz})$ の正弦波電圧 $(3.5 \mathrm{~V})$ を印加すること で梁を加振し，振幅が定常状態に達した後に振動制御を開 始した . 強制振動の制振実験結果の变位のグラフを第 12 図 に，制御電圧のグラフを第 13 図に示す .また，変位の実測 値と推定値を比較したグラフを第 14 図に示す.

第 12 图から，制振後は定常振幅を約 $80 \%$ 抑制できて いることがわかる．また，第 13 図から，制御電圧の最大值 は約 $28 \mathrm{~V}$ であることがわかる.さらに，第 14 図から，梁 の変位の推定值が実測值に収束していることがわかる.す なわち, 圧電素子のセンサ電圧のみから, カルマンフィル タにより梁の状態量を推定し，強制振動を抑制することが できることが確認された .

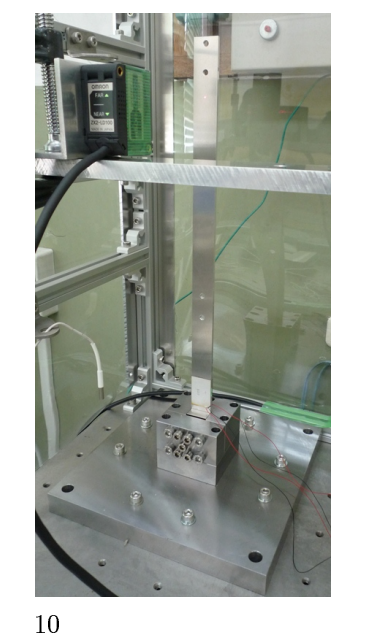

5.2 自由減衰振動の制振実験 加振用の圧電素子に梁 の固有振動数 $(26.33 \mathrm{~Hz})$ の正弦波電圧を印加することで梁 を加振し，振幅が定常状態に達した後に加振を停止し，自 由減衰振動の振動制御を開始した . また，同樣の方法て制 御なしの場合の自由減衰振動実験も行った。制御の有無に よる梁の自由減衰振動の変位を比較したグラフを第 15 図に 


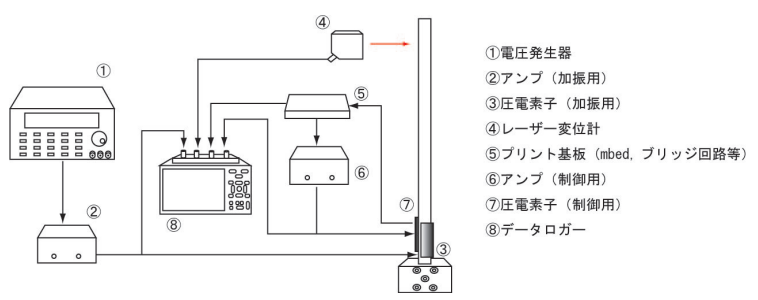

第 11 図振動制御実験のブロック線図

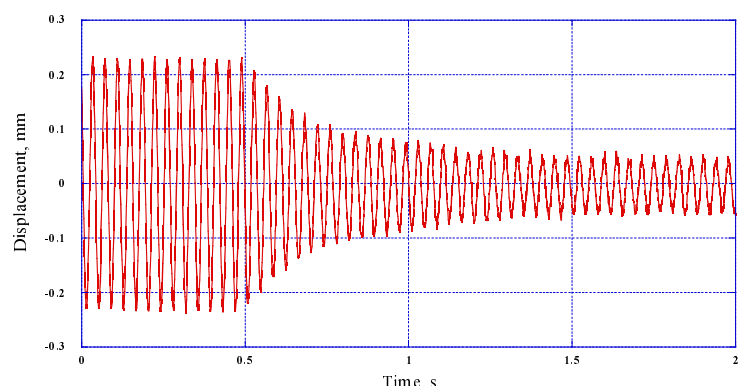

第 12 図 強制振動の制振実験結果 : 変位

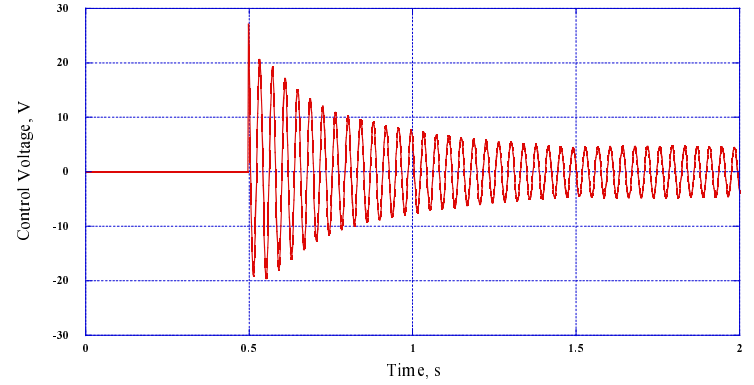

第 13 図強制振動の制振実験結果 : 制御電圧

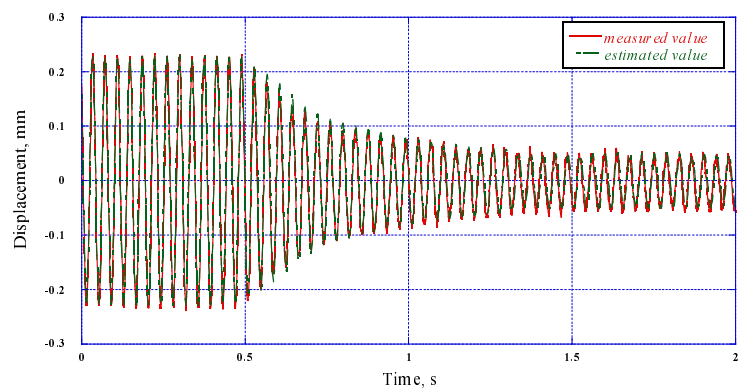

第 14 図 強制振動時の変位の実測値と推定値の比較

示す .このときの制御電圧の結果を第 16 図に示す．また， 变位の実測值と推定值を比較したグラフを第 17 図に示す．

第 15 図から，制御ありの場合には，制御なしの場合に比 べ明らかに早く振動が咸衰していることがわかる.しかし， 制御ありの自由減衰振動の時刻歴を見ると，1 次の振動が 減衰した後にも，減衰しきっていない高周波の振動が見ら れる.また，第 16 図では，一度小さくなった制御信号が再 び増加している．これは，シミュレーションには見られな かった現象である. 本実験で採用したカルマンフィルタで は, 制御モデルに梁の 1 次モードしか考慮していない，光
のため，第 17 図に示した通り，1 次モードが支配的でなく なると，状態量推定がうまくいかず，観測スピルオーバー が生じたと考えられる．また，ブリッジ回路の平衡条件が 厳密に満たされていないため, センサ情報に外乱が加わっ ていることも原因と考えられる．

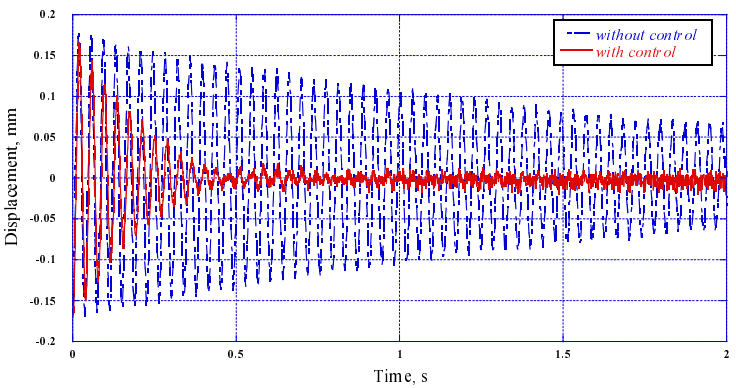

第 15 図 自由減衰振動の制振実験結果 : 变位

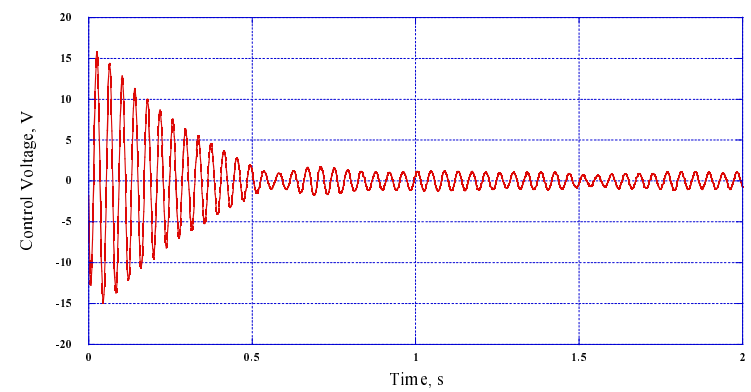

第 16 図 自由減衰振動の制振実験結果 : 制御電圧

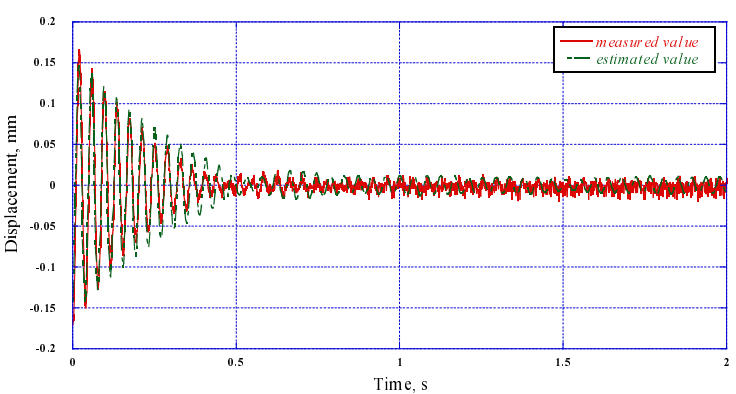

第 17 図 自由減衰振動時の変位の実測值と推定値の比較

6. 結 言

本稿では，汎用マイコンモジュール “mbed” と圧電素子 を用いた片持ち梁のセルフセンシング振動制御について述 ベた . “mbed” の利用に当たり, 電圧変換回路などから構 成されるインターフェース回路を開発することで, "mbed" に振動制御の機能を付加することに成功した .また，圧電素 子をブリッジ回路に接続してセルフセンシングを行い, 得 られたセンサ電圧のみからカルマンフィルタを用いて梁の 
状態量を推定することで , 外部センサを用いることなく振 動制御を行うことに成功した。

本研究が提案する振動制御デバイスは , 従来のセルフセ ンシング振動制御とは異なり,パソコンや $\mathrm{AD} ・ \mathrm{DA}$ 変換器 などをはじめとする複䧱な地上支援設備を必要とせず，ひ とつの振動制御ユニットとして自己完結している. 本研究 は，スマート構造をシステムとして扱い，宇宙における実 利用を見据えた研究である. 本手法及びデバイスを用いる ことで，振動制御システムを大幅に小型・軽量化すること が可能となる .今後は , この制振モジュールをさらに小型・ 高性能化し, 超高精度スマート構造システムへの適用を目 指していく.

\section{参 考 文 献}

1) Baz, J. and Poh, S.: Performance of an Active Control System with Piezoelectric Actuators, Journal of Sound and Vibration, 126, 2(1988), pp. 327-343.

2) Rawley, E. F. and de Luis, J. : Use of Piezoelectric Actuators as Elements of Intelligent Structures, AIAA Journal, 25, 10(1987), pp. 1373-1385.

3) Dosch, J. J. and Inman, D. J. : A Self-sensing Piezoelectric Actuator for Collocated Control, Journal of Intelligent Material Systems and Structures, 3, 1(1992), pp. 166-185.

4) Anderson, E. H. and Hagood, N. W. : Simultaneous Piezoelectric Sensing/Actuation: Analysis and Application to Controlled Structures, Journal of Sound and Vibration, 174, 5(1994), pp. 617-639.

5) Takigami, T., Oshima, K. and Hayakawa, Y.: Tracking Control of a Cantilever Beam using Self-Sensing Actuator based on Virtual Bridge Circuit, Transactions of the Japan Society of Mechanical Engineers, 64, 624(1998), pp. 2931-2938.

6) Forward, R. L.: Electronic Damping of Vibrations in Optical Structures, Applied Optics, 18, 5(1979), pp. 690-697.

7) Hagood, N. W. and von Flotow, A.: Damping of Structural Vibrations with Piezoelectric Materials and Passive Electrical Networks, Journal of Sound and Vibration, 146, 2(1991), pp. 243-268.

8) Wu, S. Y.: Piezoelectric Shunts with Parallel R-L Circuit for Smart Structural Damping and Vibration Control, in Proc. SPIE Symp. Smart Structures Materials Passive Damping Isolation, (1996), pp. 259-269.

9) Hollkamp, J. J.: Multimodal Passive Vibration Suppression with Piezoelectric Materials and Resonant Shunts, Journal of Intelligent Material Systems and Structures, 5, 1(1994), pp. 49-57.

10) Richard, C., Guyomar, D., Audigier, D. and Bassaler, H.: Enhanced Semi Passive Damping using Continuous Switching of a Piezoelectric Device on an Inductor, in Proc. SPIE Smart Structures and Materials Damping and Isolation, 3989(2000), pp. 288-299.

11) Clark, W. W.: Vibration Control with State-Switched Piezoelectric Materials, Journal of Intelligent Material Systems and Structures, 11, 4(2000), pp. 263-271.

12) Richard, C., Guyomar, D., Audigier, D. and Ching, G.: Semi-passive Damping using Continuous Switching of a Piezoelectric Device, Proc. SPIE Smart Structures Materials Passive Damping Isolation, 3672(1999), pp. 104-111.

13) Corr, L. R. and Clark, W. W.: Comparison of Low-frequency Piezoceramic Shunt Techniques for Structural Damping, Proc. SPIE Smart Structures and Materials Damping and Isolation, 4331(2001), pp. 262-272.

14) Onoda, J., Makihara, K. and Minesugi, K.: Energy-recycling Semi-active Method for Vibration Suppression with Piezoelectric Transducers, AIAA Journal, 41, 4(2002), pp. 711719 .
15) Makihara, K., Onoda, J. and Minesugi, K.: A self-sensing Method for Switching Vibration Suppression with a Piezoelectric Actuator, Smart Materials and Stractures, 16 2(2007), pp. 455-461.

16) Niederberger, D. and Morari, M.: An Autonomous Shunt Circuit for Vibration Damping, Smart Materials and Stractures, 15, 2(2006), pp. 359-364.

17) Takeuchi, S., Makihara, K. and Onoda, J.: Reliable and Evolvable Vibration Suppression by Self-powered Digital Vibration Control, Jounal of Vibration and Acoustics, 134, 024502(2012).

18) Makihara, K., Takeuchi, S., Shimose, S. and Onoda, J.: Innovative Digital Self-powered Autonomous System for Multimodal Vibration Suppression, AIAA Journal, 50, 9(2012), pp. 2004-2011.

19) Kwakernaak,H. and Sivan, R.: Linear Optimal Control System, Wiley, New York, 1972, pp. 220-222.

20) mbed: http://mbed.org/ (accessed 10 Sep. 2012).

\section{A.1 行 列 の 定 義}

$$
\boldsymbol{\Omega} \equiv \boldsymbol{M}_{a}^{-1}\left(\boldsymbol{K}_{a}-\boldsymbol{B}_{a} \boldsymbol{C}_{a} \boldsymbol{B}_{a}\right),
$$

$\boldsymbol{B}_{1} \equiv \boldsymbol{M}_{a}^{-1} \boldsymbol{B}_{a} \boldsymbol{C}_{a}, \quad \boldsymbol{B}_{2} \equiv \boldsymbol{M}_{a}^{-1}$,

$\boldsymbol{M}_{a} \equiv \boldsymbol{M}_{b}+\boldsymbol{M}_{p}, \quad \boldsymbol{K}_{a} \equiv \boldsymbol{K}_{b}+\boldsymbol{K}_{p}$,

$\Xi \equiv 2 \zeta \operatorname{diag}\left[\omega_{k}\right]$

$\boldsymbol{M}_{b} \equiv \operatorname{diag}\left[\rho_{b} A_{b} \int_{0}^{L_{b}} \Phi_{k} \Phi_{k} \mathrm{~d} x\right]$

$\boldsymbol{K}_{b} \equiv \operatorname{diag}\left[E_{b} I_{b} \int_{0}^{L_{b}} \frac{\mathrm{d}^{2} \Phi_{k}}{\mathrm{~d} x^{2}} \frac{\mathrm{d}^{2} \Phi_{k}}{\mathrm{~d} x^{2}} \mathrm{~d} x\right]$,

$M_{p}[k, l] \equiv \rho_{p} A_{p} \int_{x_{1}}^{x_{2}} \Phi_{k} \Phi_{l} \mathrm{~d} x$

$\boldsymbol{K}_{p}[k, l] \equiv E_{b} I_{b} \int_{x_{1}}^{x_{2}} \frac{\mathrm{d}^{2} \Phi_{k}}{\mathrm{~d} x^{2}} \frac{\mathrm{d}^{2} \Phi_{l}}{\mathrm{~d} x^{2}} \mathrm{~d} x$,

$\boldsymbol{B}_{a}[k] \equiv-\frac{b_{p} J_{p}}{d_{p}\left(x_{2}-x_{1}\right)} \int_{x_{1}}^{x_{2}} \frac{\mathrm{d}^{2} \Phi_{k}}{\mathrm{~d} x^{2}} \mathrm{~d} x$,

$\boldsymbol{\xi}(t)[k] \equiv \xi_{k}(t)$,

$\boldsymbol{f}(t)[k] \equiv \int_{0}^{L_{b}} f(x, t) \Phi_{k}(x) \mathrm{d} x$ 


\section{A.2 Nomenclature}

$\begin{array}{cll}A & : & \text { 断面積 } \\ b_{p} & : & \text { 圧電素子の電気機械結合係数 } \\ C_{p} & : & \text { 圧電素子の静電容量 } \\ d & : & \text { 幅 } \\ D_{z} & : & \text { 圧電素子の電位 } \\ E & : & \text { ヤング率 } \\ f & : & \text { 外力 } \\ H\left(x_{2}-x_{1}\right) & : & \text { ヘヴィサイドの階段関数 } \\ h & : & \text { 厚さ } \\ I & : & \text { 断面 } 2 \text { 次モーメント } \\ J_{p} & : & \text { 圧電素子の断面 } 1 \text { 次モーメント } \\ L & : & \text { 長さ } \\ n & : & \text { 計算するモード数 } \\ q & : & \text { 圧電素子の電荷 } \\ v_{c} & : & \text { 制御電圧 } \\ v_{p} & : & \text { 圧電素子の発生電圧 } \\ w & : & \text { 梁のたわみ } \\ x & : & \text { 梁の長さ方向の座標 } \\ x_{1}, x_{2} & : & \text { 圧電素子の端点位置 } \\ \delta(x) & : & \text { デルタ関数 } \\ \zeta & : & \text { 減衰比 } \\ \xi & : & \text { 梁のモード変位 } \\ \rho & : & \text { 密度 } \\ \Phi & : & \text { 梁のモード関数 } \\ \omega & : & \text { 固有円振動数 } \\ & & \\ & & \end{array}$

Subscripts

$b \quad ：$ 梁に関する量

$p \quad$ ：圧電素子に関する量 